\title{
Tourism imaginaries and the selective perception of visitors: Postcolonial heritage in Con Dao Islands, Vietnam
}

\author{
Thi Kim Phung Dang \\ Faculty of Social Sciences and Humanities, Ton Duc Thang University, Ho Chi Minh City, \\ Vietnam \\ dangthikimphung@tdtu.edu.vn
}

\begin{abstract}
Identifying the reasons why people visit places associated with death and suffering remains a key stake of dark tourism research. Such research, however, remains largely framed by Anglo-American perspectives and assumes visitors largely hail from the West. Less is known about the motivations of dark tourists from developing countries. This paper contributes to the debate by examining the case of tourism in Con Dao Archipelago, Vietnam. Once labeled as a 'Hell on Earth', the island is a famous site of both postcolonial and natural heritage, displaying former colonial prisons, prisoners' cemeteries and memorials. Over the past five years, pilgrimage tours to the tomb of Co Sau, a national hero, in Hang Duong cemetery have increasingly attracted visitors from the Vietnamese mainland. Focusing on both the supply and demand sides of dark tourism, the research uses the theoretical lens of tourism imaginaries and visitors' selective perception to investigate what attracted people to these tours. Document analysis, ethnographic observation and in-depth interviews with key informants show that a complicated set of factors (tourism commodification, geographic location, culture and beliefs) intersect to influence the emergence and transformation of penal sites' imaginaries in Con Dao Islands. Despite being presented with three different imaginaries of Con Dao, visitors from Vietnam are engaged in a form of 'spiritual tourism' focused on the sacred element of the martyrs' deaths and suffering, making this their main reason for visiting the island. The popularity of spiritual tours in Con Dao thus underlines the importance of looking at the islands' heritages beyond Western conceptions of dark and resort tourism.
\end{abstract}

Keywords: Con Dao, dark tourism, islands, selective perception, tourism commodification, tourism imaginary, Vietnam, war heritage

https://doi.org/10.24043/isj.132 • Received February 2020, accepted September 2020

C 2020-Institute of Island Studies, University of Prince Edward Island, Canada.

\section{Introduction}

Dark tourism, a concept developed by Foley and Lennon (1996), generally refers to travel to sites of death, destruction, tragedy, catastrophe and atrocity (Stone \& Sharpley, 2008). This type of recreational travel has become an increasingly prominent aspect of the tourism industry in postmodernity (Stone, 2006; Burns, 2012, p. 177; Johnson \& Brezault, 2017, p. 83), which is characterized by new forms of travel emphasizing feelings and experience 
(Dujmovic, 2015), the growth of new communication technologies and media, and increases in leisure time availability (Harrison \& Schofield, 2010). The website dark-tourism.com (2020) has recorded more than 900 dark destinations in 112 nations. Examples of popular dark destinations include the Auschwitz-Birkenau Camp (Poland) where nearly 1 million Jews died under the Nazi's genocide between 1940 and 1942 (Burns, 2012, p. 179) and 'Ground Zero' in New York City (USA) where 3,000 people were killed in the 9/11 terrorist attack on the World Trade Center.

Island tourism has become part of this broader phenomenon of dark tourism (Welch, 2015, p. 1). Situated offshore from the mainland or in distant oceans, islands have been used as locations for exile, isolation, and imprisonment in history around the world (Luo \& Grydehøj, 2017; Mountz \& Briskman, 2012). McCullock (2007) has suggested that islands have been used for prisons metaphorically as their traditional terrain is used to cut off detainees from society. Penal tourism, especially on islands, is increasingly popular (Burns, 2012, p. 177). Alcatraz in the San Francisco Bay (USA), Robben Island in South Africa, New Caledonia in the South Pacific, and Devil's Island in French Guiana, for example, are among popular destinations for island tourism (Burns, 2012, p. 177; Johnson \& Brezault, 2017, pp. 83-84).

Although dark tourism is increasingly popular, the question of why people are interested in morbid destinations, especially penal sites on islands, is still being debated, and has not yet been systematically examined (Isaac \& Çakmak, 2014). Furthermore, most of the literature on dark tourists' motivations is based on theoretical research (Isaac \& Çakmak, 2014) and focuses on the supply side of dark tourism (Stone, 2005; Rittichainuwat, 2013).

This paper helps fill in gaps in the literature on dark tourism and, more specifically, penal island tourism concerning Vietnamese engagement with the complex heritage in Con Dao. Con Dao is an archipelago of 16 islands and islets off the southern coast of Vietnam, with a total area of $75.15 \mathrm{~km}^{2}$ and a population of 8,000 . Its largest and only inhabited island, which is called Con Son, is now named the Con Dao district of Ba Ria-Vung Tau province. Because of its geographic location far from the mainland (185 km from Vung Tau city and $236 \mathrm{~km}$ from Ho Chi Minh City), the Con Dao Islands were utilized by the French to exile, imprison and torture Vietnamese uprising patriots over a 100-year period (Hayward \& Tran, 2014). During the Vietnam war with American involvement (1954-1975), the South Vietnam government, backed by the US, likewise used these islands to imprison and torture communists and political enemies (Thong, 2010). In contrast to its horrific history, Con Dao is also Vietnam's second largest marine park consisting of 14,000 hectares of marine habitat and 5,998 hectares of protected forest land (Ringer, 2012). Con Dao's political and natural attractions have presented a mixed hotspot of tourism in Vietnam, attracting thousands of foreign visitors. Once "a true hell on Earth" where 20,000 inmates died in brutality (Schneider, 2015), Con Dao is considered a Vietnamese island paradise (BBC Travel, 2015; Lonely Planet, 2016). Since 2011, Con Dao has become part of Vietnam's southeast tourism zone together with Ho Chi Minh City, Dong Nai, Tay Ninh, and Binh Duong provinces (Government of Vietnam, 2011).

The paper is based on three theoretical concepts: dark tourism, imaginaries, and selective perception. It is primarily inspired by the debate around the motivations of dark tourists. Within this wider debate, I examined visitors' motivations for visiting Con Dao island from supply and demand perspectives. By supply, I mean the presentation of the tourist destination to attract visitors, and by demand, I mean the expectations and needs that shape visitors' 
responses to such presentations. The study uses the concept of 'tourism imaginary' (Salaza, 2012; Haarhoff, 2018) to explore how and to what effect the island's image has been presented to visitors. Selective perception is used to investigate how visitors react to available tourism imaginaries of Con Dao and develop an interest in visiting the archipelago. The analysis considers how Vietnam's political, social and economic contexts, particularly the Doi Moi process, have impacted tourism. In this consideration, it pays attention to the features of postmodern tourism that take into account diverse interpretations of history and culture, and that acknowledge the individual and subjective nature of tourism (Dujmovic, 2015). The paper also adds to the discussion of experiences in postcolonial literature (Ato Quayson, 2020) with regard to how people in a formerly colonized society rethink history, especially colonial heritage.

The study is mainly based on document analysis, particularly exploring Con Dao's imaginaries. To investigate visitors' selective perceptions, this paper analyzes primary data collected during three trips to Con Dao (September 2018, April 2019 and August 2019) and also a number of interviews conducted at Binh Duong and Ho Chi Minh City.

The paper consists of five sections. Following the introduction, the paper provides a brief overview of the three concepts of dark tourism, tourism imaginary, and selective perception to set out a theoretical framework for thinking about tourism imaginaries and visitor perception as pertains to Con Dao. It then identifies different research methods used to capture visitor motivations and experiences before discussing the results of these enquiries. The paper will close with some conclusions and reflections on tourists' selective perception and factors shaping this perception drawn from the case of Con Dao.

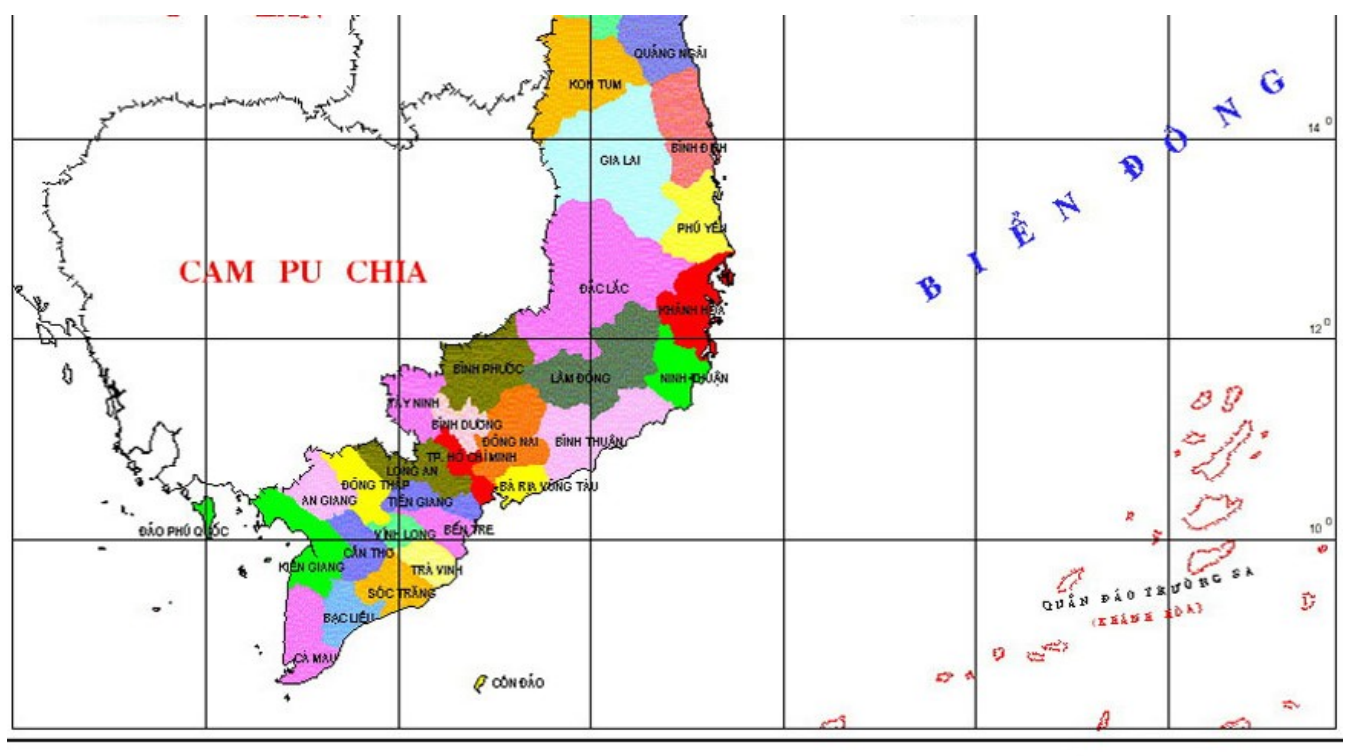

Figure 1. Con Dao in South Vietnam. Source: Adapted from https://viknews.com/vi/kien-thuc/ban-do-viet-nam.html

\section{Theoretical concepts}

The three theoretical concepts of dark tourism, imaginaries and selective perception form the theoretical framework for examining Con Dao's imaginaries and visitors' selective perceptions toward these images. 


\section{Dark tourism}

Dark tourism or thanatourism involves trips to places of "death, suffering, violence and disaster" (Stone \& Sharpley, 2008). For Dann (1998, p. 15), dark tourism is like "dicing with death," which lets visitors explore their own feelings of death. He also suggests other causes that inspire people to visit dark places, like searching for inspiration, nostalgia, and celebrating misconduct or abnormality. Wilson (2004) recognizes that certain visitors are compelled to visit dark places just for entertainment. Stone and Sharpley (2008) argue that being at the location of death and distress alone gives visitors an especially inspiring insight into the site. Some people are intrigued and fascinated by thanatological issues, so they visit dark places in a socially appropriate environment that enables them to ponder their own death. Lennon and Mitchell (2007) conclude that people's desire to see these sites may increase with contemporary interest in celebrities, popular sites, and the advancement of communication creating images of viciousness, conflicts, and disasters. Korstanje and Ivanov (2012) suggest in particular that war and dark tourism trigger feelings of excitement. The authors also believe that sacrifice is shown in nationalism and that dark tourism is a political event that brings together people with traditional knowledge, stories, and aspirations. Isaac and Çakmak (2014) argue some people view a dark place as a "must see" destination in order to promote their 'self-understanding', 'curiosity', and 'conscience'.

Despite the debates about what motivates people to visit dark places, most authors agree that dark tourism is not only about death and suffering but also about the way individuals and society perceive and justify these (Biran, Poria, \& Oren, 2011, p. 832). Since the 'darkness' of dark places is socially constructed, scholars pay more attention to the influence of sociocultural contexts on people's perception of sites of death and suffering (Stone, 2012). Considering this influence, it is important to note that most of the literature on dark tourism is based on Western perspectives and linked to Western contexts (Stone, 2012; Salaza, 2012). Although culture plays an important role in the process of making sense of unfavorable events (Korstanje \& Ivanov, 2012), the motivations of dark tourists in developing countries, often with postcolonial legacies, are poorly understood.

\section{Tourism imaginary}

The attractiveness of many tourist destinations is grounded primarily in appealing but restricted imaginaries concerning local people and their areas (Salaza, 2012). By creating a destination's 'allure', these images play a key role in providing visitors with a positive image of such places (Chi \& Qu, 2008), subsequently impacting their future selection of destinations (Haarhoff, 2018; Prayag, 2009). Imaginaries are socially constructed, adding to the sense of destinations through their interaction with the visitor's imagination about the locations (Salaza, 2012). Scholars have conceptualized the notion of tourism imaginaries in a number of ways. Lin et al. (2007) talk of tourism imaginaries in terms of cognition, affect, and the conative. Fakaye and Crompton (1991) view the concept as the mental expression of individuals with knowledge, emotions, and an overall perception of a specific destination. Chrornis (2012) discusses narrative, moral valuation, emplaced enactment, and emotional connection. Haarhoff (2018) suggests destination images are a combination of visitors' beliefs, knowledge, feelings and the overall impression regarding a specific destination. The formation of destination images is influenced by external and internal factors (Haarhoff, 2018). One of the important external factors is the provision of information about positive destination image, 
which pleases visitors and therefore leads to their loyalty to the destination (Haarhoff, 2018). Personal factors include motivation, past experience, attitudes and expectations (Haarhoff, 2018). Though using different terms, these conceptualizations appear to highlight the three themes of tourism imaginaries: general impression of the destination, knowledge of the place's attributes, and feelings toward the location. Based on this review of destination imaginaries, I use these three themes in tourism imaginaries as criteria for exploring Con Dao's imaginaries. Considering the ethical debates around travelling to sites of deaths and suffering (Stone, 2006; Stone \& Sharpley, 2008), I also incorporated a moral evaluation (suggested by Chronis, 2012) into the framework.

John Urry (2001) conceptualizes the 'tourist gaze' to address the visual images, the experience, and the feelings of tourist destinations. He notes that broader shifts in society, whether political, socioeconomic or environmental, are a major factor in visitors' attitudes, experiences and feelings toward destinations. As tourism agencies promote destination images, they pay attention to the preferences and aspirations of visitors and also shape them through their activities. There is a recursive relationship between a tourist attraction and the site's visual evaluation criteria, design, and representations. Various images are authorized by various discourses and have implications for place organization. Influenced by Urry's view on the tourist gaze, my examination of Con Dao imaginaries considers the Doi Moi process' broader socioeconomic background and development in Vietnam in this era. This examination pays special attention to how these images represent a distinctive characteristic of late-modern heritage: "critical engagement with the spaces in which the past intervenes in present” (Harrison \& Schofield, 2010).

Bruner (2005) argues that imaginaries can be both firmly settled in certain locations and that there is a recursive relationship between tourist tastes and aesthetic judgment expectations on the one hand and a site's design and representation on the other. Different views or images are permitted by different discourses and open to change under the influence of sociocultural structures and politics. Most studies of tourism imaginaries center around their formation and give little consideration to the connection between tourist perceptions and tourism imaginaries. As a result, little is known about the impact that tourist perceptions have on the emergence/transformation of tourist imaginaries and vice versa. The present paper thus pays attention to factors related to the emergence/change of tourism imaginaries. It places special focus on exploring the link between Con Dao imaginaries and visitors' perceptions of these images.

\section{Selective perception}

Perception is an overall personal image of the world, framed by the data that individuals later recover (Hudson, 2008). Tourist perceptions of a destination's image as a favored option when voyaging is significant for the travel industry (Ragavan, Subramonian, \& Sharif, 2014). Affected by an individual's feelings, assessments, and experiences (Reisinger \& Dimanche, 2010), individual perception may not really constitute the genuine response of the target reality (Sylvester \& Cherry, 2007). Perception is regularly selective (Moutinho, 1987; Mouthino \& Vargas-Sanchez, 2018) inasmuch as individuals interpret distinctive stimuli in various ways, overlooking certain components while strengthening others (Hudson, 2008). Selective perception conceived along these lines alludes to "observation of the chosen reality related to their own needs, emotions and beliefs" (Reisinger \& Dimanche, 2010). It is selective perception that affirms the attractiveness of a given tourist destination (Leite, 
Castañeda, \& Adams, 2019). Selective perception has also been associated with the length of time for which a traveller is inclined to visit a destination (Seaton \& Bennett, 1996). Selective perception is communicated by a visitor's selective attention and selective distortion (Moutinho \& Vargas-Sanchez, 2018). Selective attention is a visitor's attention to stimuli relevant to their need and interests. Selective distortion is a visitor's tendency to change information in a way that has individual importance. National culture is believed to be a factor that shapes selective perception (Reisinger \& Dimanche, 2010) on the grounds that individuals are regularly mindful of what is similar to their cultures and compares to their cultural standards.

To investigate visitors' selective perceptions of Con Dao's imaginaries, the present paper focuses on what imaginaries and attributes of imaginaries visitors pay attention to and whether/ how/why these images are distorted. In his notion of the tourist gaze, Urry (2001) points out that visitors' desires to see certain places and their ways of appreciating them are not just individual but are socially structured. This visual dimension concerns not only the actual experience of visitors travelling to destinations, but also their daydreaming that anticipates the holiday and shapes their expectations. What people 'gaze upon' are perfect reflections of their perceptions taken from various media (Urry, 2001). The examination of selective attention and selective distortion of visitors' perceptions to Con Dao, adapted from Urry, pays attention to relevant socioeconomic factors.

\section{Research methods}

To investigate Con Dao's imaginaries and visitors' selective perception, the research employs a combination of methods, including literature review and document analysis of research papers, book, newspaper articles, and tourism company advertisements in Vietnam. To identify the island's major tourism imaginaries, the author conducted a thematic analysis of information from 30 websites of tourism companies situated in Ho Chi Minh City, Hanoi city, and Con Dao town. The analysis focuses on the four components of tourism imaginaries (general impression, attributes of the place exposed by tourism activities, moral valuation, and feelings associated with the islands). Selective perception was identified from semi-structured interviews with 130 individuals, including visitors, tour guides, tourism companies and local people. The interviews took place in 2018-2019 at Con Dao, Binh Duong, and Ho Chi Minh City, focusing on the respondents' main perception of the islands through the imaginary/part of the imaginary they paid attention to and how this imaginary/part of this imaginary was distorted to match their needs and expectations. Data was also enriched by the author's participatory observation at Hang Duong cemetery.

\section{Research findings}

Research findings from the thematic analysis reveal three main imaginaries of Con Dao in Vietnam's tourism: a dark (historical) image, a green (natural) image, and a light (spiritual) image. The results also highlight a significant selective perception on the part of visitors regarding these imaginaries. 
Con Dao's dark (historical) imaginary

Con Dao was considered 'Hell on Earth' during the first Indochina war when the French colonizers used a complex of prisons there (built from 1861) to torture and detain Vietnamese patriots (Nguyen, 2012). That complex was then used by the South government during the Vietnam war to punish political enemies and communist figures. Information about cruelty toward detainees in Con Dao during the Vietnam war was exposed in newspapers in Saigon before 1975 (Duong \& Be, 2012). The photos of prisoners in Con Dao's tiger cases by Tom Harkin, a former U.S. Senator, appeared in Life Magazine on July 17, 1970, causing waves of outrage from Americans (Luce, 1970). After the country's unification, the island became famous with a photo called 'The Reunion Day', which was awarded the Certificate of Honor (Mencin Honor) at the International Photography Congress held in Spain in 1991, by Vietnam News Agency correspondent Lam Hong Long depicting the reunion of a death row prisoner with his elderly mother after he was released from Con Dao and back to the mainland in Vung Tau harbor (Huy Han, 2019). After the war, stories from Con Dao's former political prisoners about their harsh imprisonment were frequent in newspapers, enhancing the overall impression of the island as a 'Hell on Earth', featuring prisoners' extreme isolation, suffering, and death caused by the rulers' cruelty (Huong Giang \& Minh Phuong, 2013; Thong, 2010; TN, 2005).

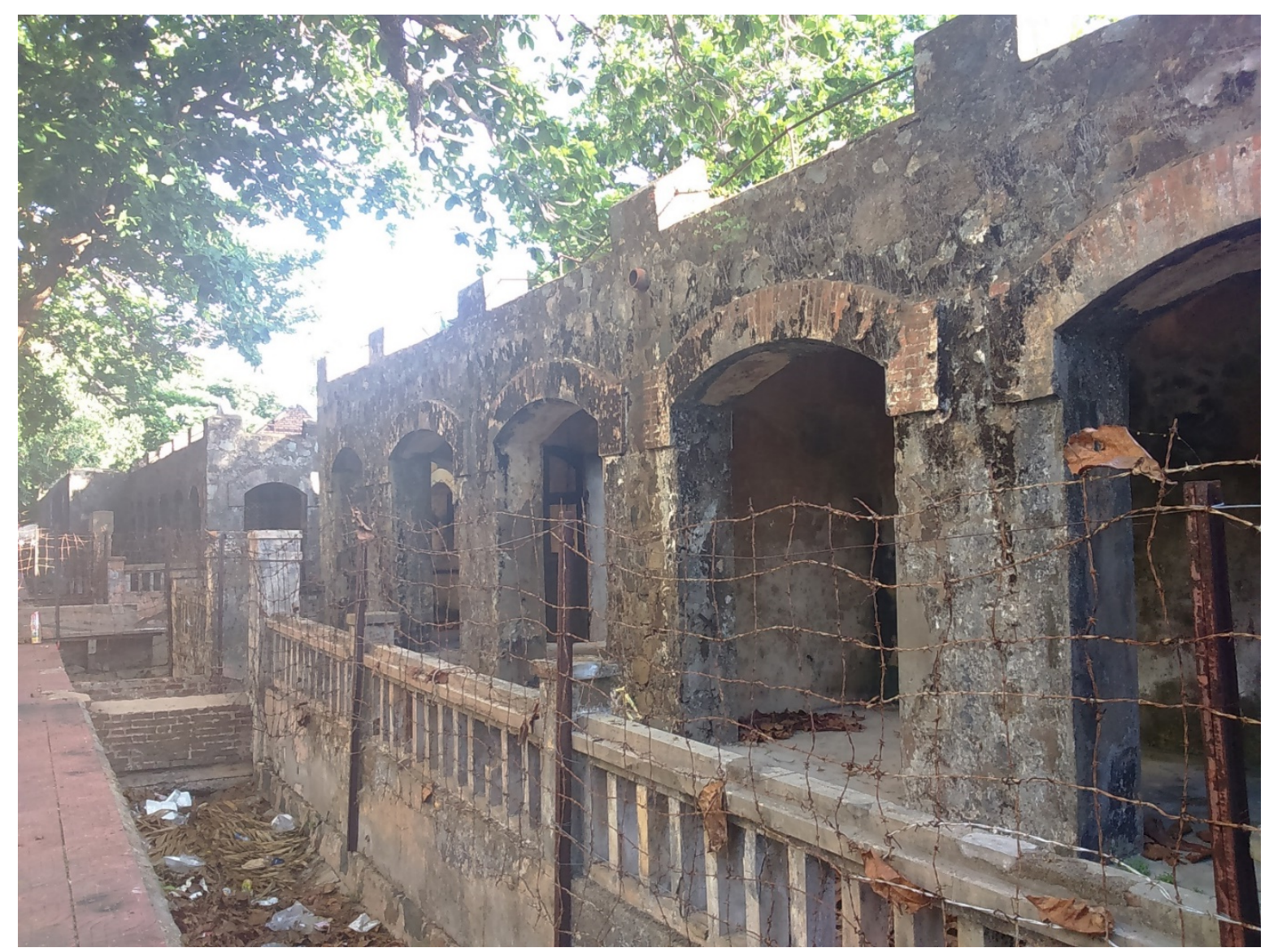

Figure 2. Phu Hai detention camp. Source: Thi Kim Phung Dang, 2019. 


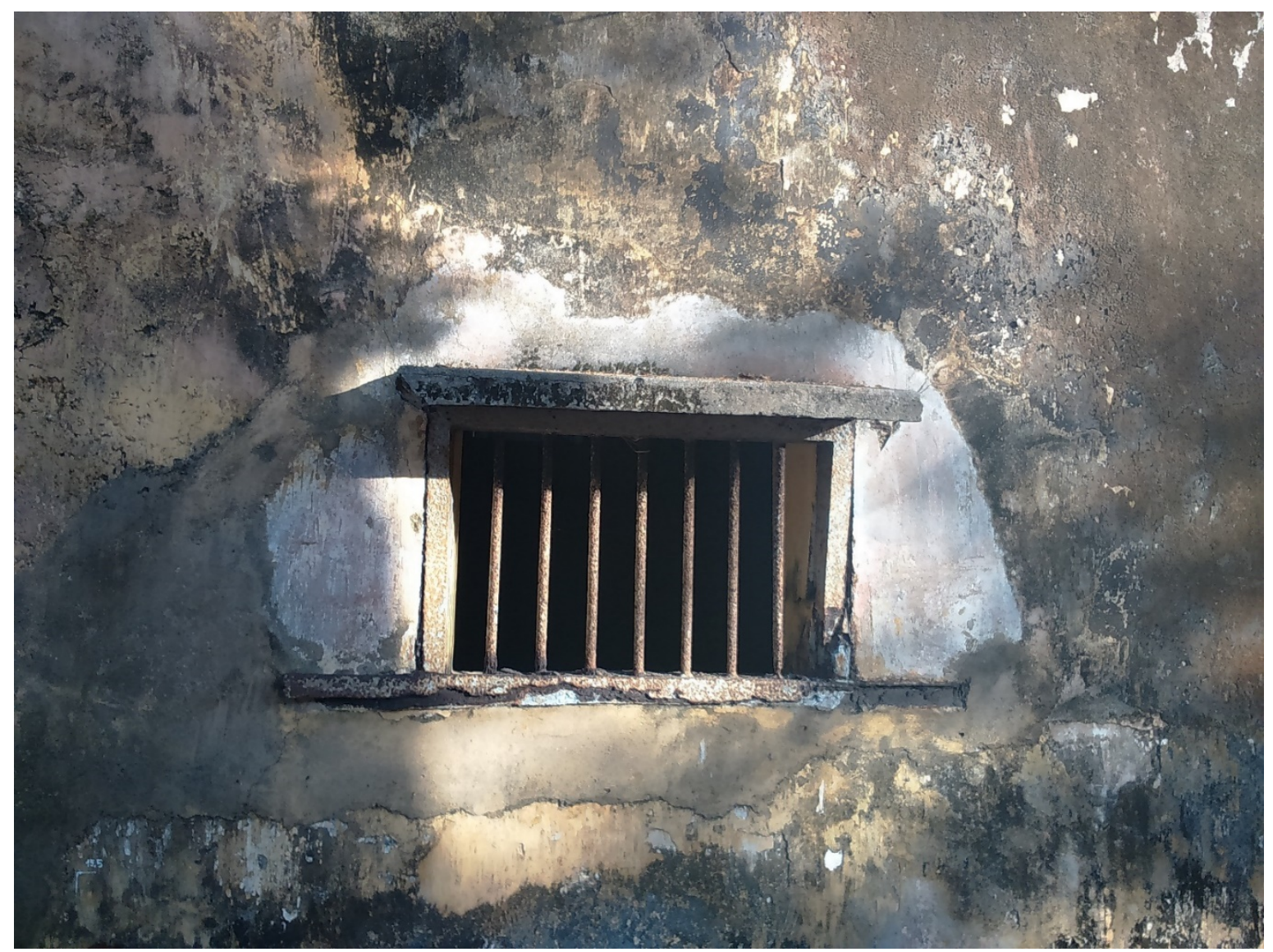

Figure 3. A cell window at Phu Hai camp. Source: Thi Kim Phung Dang, 2019.

In the late 1970s and 1980s, the dark image of Con Dao inspired 'back to the roots' (Vì nguồn) tours, which were primarily initiated by veterans, former prisoners, and government officials to visit the island in memory of their fallen comrades. In some cases, these trips also included young students with the purpose of teaching them about the country's heroic history, intended to foster gratitude towards their fathers, heroes and martyrs in the first and second Indochina wars. These tours helped create a popular image depicting Con Dao as an isolated island for political exile with narrow, wet and dark cells, detention camps, solitary confinement, tiger cages, and large prisoners' cemeteries. The lack of fixed links (bridges, tunnels) to Con Dao enhanced the island's remoteness, and as such made the image extremely dark and mysterious. At the center of this image are political prisoners who were physically and mentally tortured in the Dark Room, Rice Mill, Torture Chamber, and Dark Dungeon. The image likewise featured their destinies with Hang Keo and Hang Duong cemeteries where around 200,000 prisoners were buried after dying or being killed.

This dark image, however, evokes two contradictory feelings. On the one hand, it is a feeling of indignation and hatred for the brutality and atrocity of the forced hard labor, torture, murder, death and suffering in and around the detention camps. On the other hand, it is admiration of and gratitude for the tenacity, strong will, courage, dedication, greatness, unyielding spirits and patriotism of national heroes like Le Hong Phong, Nguyen An Ninh and Vo Thi Sau. The moral evaluation here is one of humanity and revolutionary optimism, which helped the heroes overcome tragedy to fight for their country. This moral evaluation 
has been highlighted in Vietnam' social media as an aspect of national identity, which has helped the country survive and develop despite its difficult history, ravaged by wars.

However, there has been a shift in the provision of this imaginary in Vietnam's tourism over the past decades. The tone of the narratives has been softened under the Doi Moi, a process of political and socioeconomic reform that began in Vietnam in 1986. Doi Moi has advanced the development of a market-oriented economy with multiple stakeholders and promoted the increasing integration of Vietnam into the global world (Beresford, 2008). With these policies, Vietnamese leaders and social media have recently talked about leaving hate and anger behind to move forward, making friends with other countries, including old enemies (LĐO, 2018; TTXVN, 2015; Viet Quang, 2016). Companies operating Về nguồn tours now mainly focus on the 'positive' aspects of the narrative: honoring the bravery and strong will of the national heroes and martyrs. On travel company websites, the name 'Hell on Earth' has been replaced by other names, such as 'Legendary Con Dao' (VietSense Travel, 2019; Fiditour, 2019; Zoom Travel; Lien Bang Travel, 2019), 'Historic Island' (Con Dao Tourism, 2019), and 'Sacred Land' (VietSense Travel, 2019). The destinations of these tours include prisons (Phu Son, Phu Hai), American tiger cages (Phu Binh camp), French tiger cages, solitary cow cages for torturing prisoners, the rice mill tunnel, dark torture chambers, and cemeteries (Hàng Duong and Hang Keo). Nevertheless, tour guides focus on telling audiences about the 'proud' side of the image: how political prisoners overcame guards' torture and brutality to continue their lives and activities in dark cells, resisted the forced salute of the enemy's flag, organized political classes, recruited new party members, shared food and took care of each other like family members (Nguyen, 2019; Pham, 2014; Phung, 2019).

\section{Con Dao's green (natural) imaginary}

The isolation, remoteness and small population of the archipelago give it an advantage. The island nature is less disturbed by human activity than other parts of the country (Ringer, 2012). The establishment of Con Dao National Park (CDNP) in 1993 helped establish a green image for the archipelago, which includes both forest and marine landscapes. Doi Moi's new market-oriented economy and global integration policies have promoted private investment, especially foreign investment, into Con Dao's tourism, and the development of luxury resorts such as the Six Senses in 1995 further enhanced Con Dao's green image, inviting tourists to escape from their busy lives.

The effort to build a green image for the archipelago has recently been driven by both CDNP and travel companies. They employ the archipelago's wilderness attributes (forests, sea) to paint the picture of an attractive hideaway for visitors, who are capable of taking luxury trips to escape the hustle and bustle of life in the big cities of the mainland. CDNP promotes ecotourism, which was introduced into Vietnam in the mid-1900s (Pham, 2017) and has been developing in Vietnam since the 2000s (Nguyen, 2016). CDNP operates forest tours to Dam Tre Bay, So Ray Plantation, and Ong Dung Beach. With a campaign to protect marine biodiversity, it also provides marine ecotours: watching turtles lay eggs on islets such as Hon Tai, Tre Lon, Hon Cau, and Bay Canh; diving to explore coral reefs at Tai islet. These tours aim to advance a moral evaluation of the green image, highlighting biodiversity/nature conservation.

In CDNP's own words: 
Con Dao, in addition, is a very precious natural resource of the country, with high potential biodiversity, a national genetic conservation, a congregating site for the flora and fauna originate from the northern, central and part of Vietnam (Con Dao National Park, 2019).

On the tour operator websites, it is common to see photos of the archipelago's beautiful forest and marine landscapes. While the dark image depicts cells and detention camps, these websites describe Con Dao's startling and charming natural beauty (Con Dao Tourism, 2019). Highlighted attributes of the island's wilderness include the immense blue sky, sunshine, pristine beautiful beaches with white sand (Vietravel, 2019), colorful coral reefs and a dazzling underwater world, unspoiled nature on small islets, marine landscapes, the wilderness, primary forests, fresh air, beautiful sunsets, and peaceful local life. The name of 'Hell on Earth' has been completely replaced by 'The Sea Heaven' and 'Paradise on Earth'. Instead of a difficult emotional experience, tourists are promised relaxation and enjoyment. Instead of just visiting and seeing remnants of detention camps, tourists are introduced to various activities, such as swimming, snorkeling/scuba diving to explore coral reefs, observing turtles laying eggs, sunbathing, trekking, walking, taking pictures, and climbing. Attractive destinations include islets (Hon Ong Dung, Hon Bay Canh, Hon Tai), Hill of the Cross, Mountain of Love, Ben Dam port, An Hai beach, and Dam Trau beach. The main narrative of tour operators focuses on tourists' interactions with nature. The following quotes taken from various travel operator websites emphasize the green imaginary of the island:

With mainly mountainous terrain intertwined with primeval forests and the sea, Con Dao island district (Ba Ria - Vung Tau) is not only famous for its natural beauty, wild beaches, pristine, fine white sand captivates tourists everywhere, but it is also famous for seafood, indigenous people and more than a place that preserves the rich history of culture and the heroic revolution of nation. (Vietravel, 2019)

Guests also have the opportunity to experience the nature of the sea and islands Extremely beautiful beaches of Con Dao. (VietSense Travel, 2019)

Traveling Con Dao to mingle with the wild nature here. Con Dao is a resort paradise and is voted as one of the 10 most beautiful islands on the planet by Travel-Leisure Magazine, possessing beautiful beaches and attractive primeval forests. Tourists come to visit and relax. [...] Con Dao Tour at Fiditour Travel will take you to visit and explore the unspoiled nature of the island such as: Visiting Bay Canh island, primary forest, Dam Trau beach or learn about the majestic history of Con Dao. (Fiditour, 2019)

Explore tranquil forests, white sandy beaches, colorful coral reefs and a dazzling underwater world. (Lechee Tour, 2019)

$14 \mathrm{~km}$ from the center of the town and $12 \mathrm{~km}$ from Co Ong airport, Dam Trau is an ideal destination for picnics, swimming, watching, and exploring the remote islands. (Vntrip, 2019) 
In general, beautiful nature is at the center of this image, calling for people to come and enjoy. The development of moveable links (ferries, airlines) since 2009 has facilitated budget ecotours to Con Dao. Vietnamese youths enjoy engaging in phuọt (budget travel) to the island.

\section{Con Dao's light (spiritual) imaginary}

The dark image of Con Dao contains large cemeteries for prisoners, with the largest being Hang Duong, at which are buried revolutionary leaders and figures of Vietnam's Communist Party. The first female death row prisoner on the island, Vo Thi Sau, is among these figures. In national memory, Vo Thi Sau, often respectfully called Co Sau, is one of the country's major heroes because she fought and died for its independence as a young guerrilla. She was captured, imprisoned and then executed at the age of 19 (1943) in Con Dao by French colonial authorities. According to islanders and tour guides, local people often show respect for her sacrifice by worshipping her tomb and offering flowers and incense. Local myths around her sacred power have spread, and locals come to her tomb to pray and make wishes. In particular, fishermen often visit her tomb before sailing off to pray for their safety at sea.

Observing the spread of this local myth, tourism companies have developed spiritual tours to visit Co Sau's tomb, which has become a popular tourism product on the island since the mid-2010s. On the websites of the big tourism operators, such as Vietravel and Saigon Tourist, these tours have taken the spotlight. Old prisons and other dark places of Con Dao have become secondary or supplementary destinations on these tours. Tour guides in Con Dao state that they often take tourists to visit her tomb in order to pray. These tours are now advertised, with elaborate guidance on offering items, flowers, and the appropriate wording of the prayer. Interviews with local tour guides and taxi drivers show that an estimated $80 \%$ of tourists, mostly from the North of Vietnam, visited the island for spiritual tours. The number of spiritual tours grew further after the introduction of high-speed ferries and airlines to Con Dao. During peak seasons (Tet holiday, summer holiday), the number of tourists arriving per day may reach 2,000 (compared to the island's population of 8,000). Tourists often visit the tomb at midnight, offering food, flowers, and prayers. Since the number of visitors increased significantly, the management board of the cemetery had to set the rule that every individual/group has only 10 minutes for worshipping and must place offered items in an orderly manner at designated locations. The board also has staff to supervise visitors' adherence to this rule. The growth in spiritual tours, with an increasing number of visitors, has in some senses benefited the island's residents as it has promoted local jobs and businesses providing transportation, accommodation, food services, gifts, offerings, etc.

Spiritual tours have thus made Con Dao a destination for pilgrims. The name 'Hell on Earth' has been replaced by other names, such as 'Sacred Island', 'Spiritual Con Dao', and 'Legendary Con Dao'. Hang Duong cemetery, where nearly 2,000 independence fighters and prisoners are buried, has become a holy site for praying for peace, wealth and happiness. Instead of indignation and despair, this sacred image evokes feelings such as admiration, appreciation and hope. The moral evaluation of the imaginary is people's worshipping of the hero, who sacrificed her life for the country and thus became a goddess with supernatural powers. It may be said that the spiritual image is a reflection of the dark image, which distorts the hero's sacrifice into a sacred image. In spite of the fact that the centre of the spiritual 
imaginary is Co Sau, with her blessed force as a goddess, the visits are closely linked to the visitors' wishes and expectations for their own lives.

With many unique, attractive travel programs to Con Dao departing from Hanoi, Ho Chi Minh City, professionally organized by VietsenseTravel will take visitors to the legendary Con Son historic land, to learn together a glorious past of our nation in Con Son. And burn incense together to pay our gratitude to the fathers and brothers who sacrificed to restore peace forthe country. (Vietsense Travel, 2019)

Con Dao tour with super-promotion in the Golden Autumn 2019-departure from Ha Noi will bring you to the sacred land of Con Son, the nation's hero Vietnam, visit the tomb of hero Vo Thi Sau. Guests also have the opportunity to experience of the beautiful scenery of the island, which was dubbed the "one in the 9 most mysterious islands in the world." (VietSense Travel, 2019)

Table 1. Dark imaginary $v s$ Green imaginary $v s$ Light imaginary.

\begin{tabular}{|c|c|c|}
\hline Dark imaginary & Green imaginary & Light imaginary \\
\hline \multicolumn{3}{|l|}{ General impression } \\
\hline - Hell on Earth & $\begin{array}{l}\text { - Paradise on Earth } \\
\text { - Sea Heaven } \\
\text { - Tropical paradise } \\
\text { - Relaxation paradise }\end{array}$ & $\begin{array}{l}\text { - Sacred land } \\
\text { - Legendary Con Dao } \\
\text { - Historic land/destination } \\
\text { - Revolutionary island }\end{array}$ \\
\hline \multicolumn{3}{|l|}{ Attributes } \\
\hline $\begin{array}{l}\text { - Detention camps } \\
\text { - Dark, narrow, humid cells } \\
\text { - Cow cages, tiger cages } \\
\text { - Cemeteries, Pier } 741 \\
\text { - Suffering, torture } \\
\text { - Death } \\
\text { - Forced labor }\end{array}$ & $\begin{array}{l}\text { - Beautiful forest and } \\
\text { marine landscapes } \\
\text { - Clear sea, white sand } \\
\text { beaches } \\
\text { - Deserted coach road } \\
\text { - Walking, trekking } \\
\text { - Swimming, diving } \\
\text { - Sunbathing }\end{array}$ & $\begin{array}{l}\text { - Heritage sites } \\
\text { - Cemeteries: holy places for } \\
\text { worship and prayer } \\
\text { - Nation's glorious past } \\
\text {-Worshiping } \\
\text { - Wishing } \\
\text { - Praying }\end{array}$ \\
\hline \multicolumn{3}{|l|}{ Moral valuation } \\
\hline $\begin{array}{l}\text { - Indignation about atrocity } \\
\text { - Paying tribute to heroes' } \\
\text { resilience, patriotism, } \\
\text { revolutionary optimism }\end{array}$ & $\begin{array}{l}\text { - Appreciation of natural } \\
\text { beauty } \\
\text { - Nature conservation }\end{array}$ & $\begin{array}{l}\text { - Appreciation of present } \\
\text { and future life, concerning } \\
\text { wealth, health, peace, } \\
\text { happiness }\end{array}$ \\
\hline \multicolumn{3}{|l|}{ Feeling } \\
\hline $\begin{array}{l}\text { - Indignation } \\
\text { - Hatred }\end{array}$ & $\begin{array}{l}\text { - Relaxation } \\
\text { - Enjoyment } \\
\text { - Entertainment }\end{array}$ & $\begin{array}{l}\text { - Gratefulness for ancestors' } \\
\text { sacrifice } \\
\text { - Admiration of Co Sau's } \\
\text { supernatural powers } \\
\text { - Hope }\end{array}$ \\
\hline
\end{tabular}


Visitors' selective perceptions of the island

Since smart phones and internet access have become widespread in Vietnam, it is unsurprising that $90 \%$ of respondents said they knew about Con Dao from social media and tour operator websites. 50\% had also heard about Con Dao from friends, relatives, family members, and acquaintances (mainly concerning the spiritual imaginary). $89 \%$ of respondents mentioned the names of national heroes associated with Con Dao, such as Vo Thi Sau, Nguyen An Ninh, and Le Hong Phong.. It should be noted that when they mentioned Hang Duong cemetery, they often referred to it as a holy site. Notably, 95\% of respondents paid more attention to spiritual tours to Co Sau tomb for prayer and worship than they did to other tours to Con Dao.

Being exposed to the three imaginaries of Con Dao through social media and tourism advertisements, respondents' perceptions of the islands appear to be a mixed one, indicating a significant shift from the long-held image of 'Hell on Earth'. Overall, 85\% think of the island as a place for touring and relaxing together with visiting historical places. Despite the widespread advertisements regarding the island's green image, respondents still offer very sketchy attributes of this image, such as beautiful nature, fresh air, and friendly locals. They also do not mention forest and marine biodiversity or nature conservation. The mixed imaginary in respondents' perceptions contains more attributes of the dark and light images of the island. This may be because of the long history of the dark image, which persists in Vietnamese social media. Nevertheless, while some respondents mention cells, detention camps, prisoners' suffering, and death, they mostly focus on the 'positive' immaterial aspect of the dark image: the sacrifice, strong will, and patriotism of national heroes. Respondents seem to feel more comfortable with the light image than the dark image because, with the former, they have fewer uncomfortable feelings while still being able to pay their respects to the unyielding heroic spirits of revolutionary prisoners against occupation and their harsh living conditions in the prisons. Some visitors' reasons for visiting Con Dao are presented in Table 2.

Table 2. Visitors' motivations for visiting Con Dao.

\begin{tabular}{|c|c|}
\hline $\begin{array}{l}\text { Visitor } \\
\text { type }\end{array}$ & Motivations \\
\hline $\begin{array}{l}\text { Veterans } \\
\& \text { former } \\
\text { political } \\
\text { prisoners }\end{array}$ & $\begin{array}{l}\text { - To recall memories of the past, visit the battlefield, and light incense for } \\
\text { comrades. } \\
\text { - To educate the next generation regarding history and uphold the pride of the } \\
\text { nation. }\end{array}$ \\
\hline Others & $\begin{array}{l}\text { - To know the extent of wartime devastation. } \\
\text { - To honor the fighting spirit of national heroes and to show respect to the hero } \\
\text { Vo Thi Sau. } \\
\text { - To learn about the memories of war, it is necessary to learn about the sacrifices } \\
\text { of the heroic martyrs. } \\
\text { - To learn about a place of historical heroes, which is attracting international } \\
\text { visitors, veterans, women, young students. } \\
\text { - To learn about the war history of the homeland and the national hero Vo Thi Sau. } \\
\text { - To worship and offer incense at Co Sau tomb, praying for good things for } \\
\text { myself and my family. } \\
\text { - This tour is a combination of visiting the natural beauty of Con Dao, resting, } \\
\text { and visiting Co Sau's tomb. }\end{array}$ \\
\hline
\end{tabular}




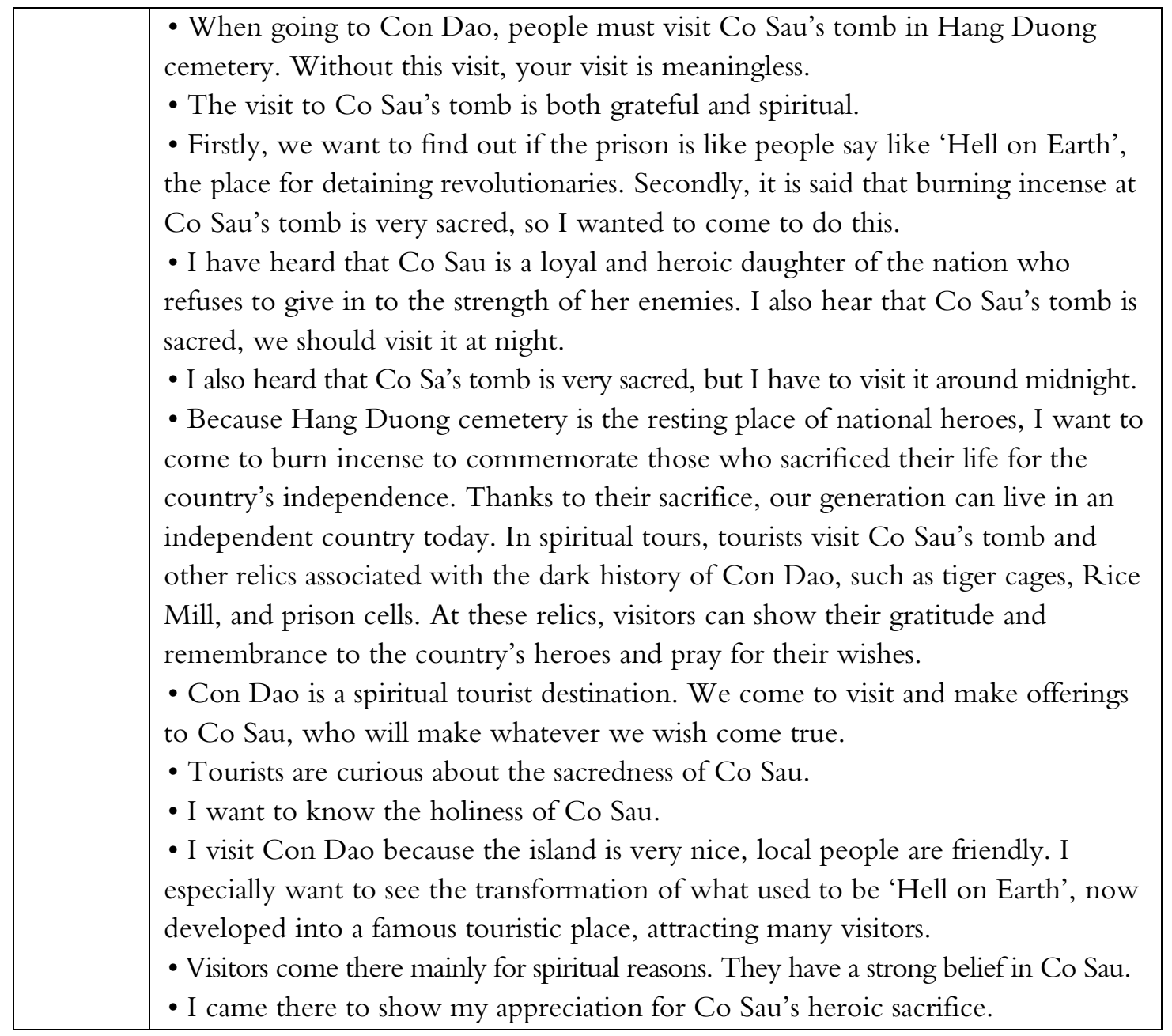

These statements reveal visitors' selective perceptions regarding the island, including their selective attention and selective distortion. For visitors' selective attention, although the dark image is still present in their mind, they pay more attention to its modified version, the light image of the island. The main place they want to visit is Co Sau's tomb, not the prison camps. This selective attention places greater emphasis on positive feelings than does the idea of 'Hell on Earth'. Visitors' selective distortion is evident in the fact that the hero Vo Thi Sau is considered a holy goddess. People's gratitude for her sacrifice has turned into their worshipping her supernatural powers. Although they know about the darkness of the island's history, they prefer to distort it by attaching spiritual meaning to the place.

This distortion shows how visitors choose to ignore some brutal aspects of the horrific past and link the imaginary to their own needs and expectations. By concentrating on their expectations and wishes rather than historical events, visitors place themselves at the center of the island's imaginary. The moral evaluation here is all about life. It is life in the past when revolutionary optimism and patriotism helped prisoners overcome their tragedy to stay alive and fight. It is also life in the present when visitors appreciate their peaceful life following the dark history of the islands. It is furthermore about life in the future when visitors pray at Co Sau's tomb, wishing for wealth, health and happiness.

Nevertheless, some respondents complain that these spiritual tours distort the true sense of the national heroes' sacrifice. One respondent says that most participants on these tours are businesspeople and states: 
In my opinion, we should continue to develop tours such as visiting the tomb of Co Sau in Con Dao to burn incense to commemorate the heroes. But this practice should not be employed for superstition to get status, titles and personal benefits.

\section{Discussion}

This paper contributes to discussions surrounding the factors that attract visitors to penal heritages on islands like Con Dao, a historical island site in southern Vietnam.

Research findings show that tourists' motivations for visiting Con Dao Archipelago is influenced by both the supply and demand sides of dark tourism. On the supply side, 'positive' immaterial attributes of dark places in Con Dao are highlighted to attract visitors. Heroes' patriotism, strong will, bravery, and resilience contribute significantly to the meaning of the venues. On the demand side, visitors' selective perceptions determine which images/parts of images they pay attention to, thereby forming their motivations for seeing dark places.

A number of factors appear to influence changes in Con Dao's tourism imaginaries to meet visitors' selective perceptions. The emergence of new tourism imaginaries of the island (green and light images) alongside its well-established dark image are being driven by tourism commodification under the country's socioeconomic development. Characterized by various material and immaterial attributes, the three imaginaries (dark, green, light) present conflicting general impressions, changing from 'Hell on Earth' to 'Paradise on Earth' to 'Sacred Island' respectively.

The development of these three Con Dao imaginaries suggests the impact of broader socioeconomic contexts on tourism, as Urry (2001) notes. Overall, the country's socioeconomic development and integration with the world have enabled Vietnam's government to soften the tone of its difficult heritages. These changes give tourism companies more room to recreate and even misrepresent heritage imaginaries that meet changing visitor expectations. Economic growth also provides the tourism industry with a new generation of tourists who did not experience the wars and instead wish to concentrate on enjoying a peaceful life. The commodification of spiritual tours in particular accommodates visitors' expectations and wishes for wealth and happiness.

Geographic conditions (remoteness, isolation), culture, and beliefs significantly shape the popularity of Con Dao's spiritual image. Islands have long been viewed by Taoism and Buddhism as sacred and holy locations (Luo \& Grydehøj, 2017). Such a connection is relevant in the case of Con Dao's spiritual imaginary, considering that Vietnamese folklore is greatly influenced by Taoism and Buddhism. In addition, Vietnamese people have a longstanding folk religion of worshiping ancestors as well as historical heroes (Anh, 2015; Vu, 2006). For example, the imperial prince Tran Hung Dao of the Le Dynasty, who twice helped the country's armies defeat Mongol invasions in the $13^{\text {th }}$ Century, became a deity in Vietnamese folk belief. Therefore, it is unsurprising to see people viewing Co Sau, a hero of the country, as a goddess. In particular, the tradition of worshipping Mẫu (Mother Goddess/Holy Mother) in folk belief $(\mathrm{Vu}, 2006)$, which highlights feminine power, might help explain why the spiritual imaginary has focused on this one female hero in particular, among the multitude of heroes' tombs in Hang Duong cemetery. The ideology of Mẫu religion, focusing on what 
people gain in their present life, such as health, success, social titles and happiness ( $\mathrm{Vu}, 2006)$, is also reflected in visitors' worship and prayers.

Informed by three distinct imaginaries, visitors' selective perceptions of Con Dao are not a black-and-white or either/or picture but instead a blend between the dark and green images, paying more attention to the holiness of death and suffering than to its violence. Con Dao's dark image as 'Hell on Earth' is thus giving way to a mixed image (a place for both relaxation and worship), in which the spiritual element is becoming more and more popular. Visitors and their desires and expectation for peace, wealth, health, success, and happiness are at the heart of the mixed image. The moral value of the image is changing from hatred and indignation regarding human atrocity to visitors' worshiping of a national hero for their hopeful expectations about both their present and future lives.

The development of three tourism imaginaries in Con Dao reflects the distinct features of dark tourism in a postcolonial country like Vietnam, where dark locations are often associated with wars of independence. The softening of the dark imaginary's narrative underscores the 'positive aspects' of its brutal history: the courage, resilience, and sacrifice of national heroes. These elements have been regarded as crucial to the national identity of a country that had to struggle for its independence throughout most of its history. The connection between dark sites and national identity illustrates one difference between Vietnamese and Western dark tourism, given that even dark tourism sites in the West are rarely linked to colonial oppression. In addition, the spiritual imaginary highlights a central issue in how people in former colonies rethink and reframe their colonial heritage (Ato Quayson, 2020). This rethinking or reframing of heritage is closely related to the Vietnamese tourism industry's strategy for responding to the postmodern holiday: diversifying forms of vacation to meet the expectations of a new generation of travellers who have more time to travel and who are seeking a more emotional and experiential vacation (Dujmovic, 2015).

The development of Con Dao's imaginaries is particularly linked to islandness, an important concept in island studies. Islandness typically refers to geographical, social and political characteristics of islands that make them distinct from mainland areas (Jackson, 2014; Hall, 2014). The study findings confirm that the three Con Dao imaginaries focus on purported island attributes, including wilderness (forest, sea, biodiversity), isolation, and low population. Con Dao's isolation from the mainland makes its wilderness less disturbed by humans, which then allows it to serve as a hideaway for tourists who are intrigued by the green imaginary. The dark imaginary has been colored by historical memories portraying how colonialists and the old regimes before the country reunification in 1975 used the island's isolation to practice their dominance and control over prisoners, and inflict cruelty on their bodies and spirits. Interestingly, Con Dao's isolation was used in both the politicized narrative emphasizing brutal aspects of the island's dark image and the softened narrative highlighting the strong will, bravery and resilience of national heroes, which have been considered as key to national identity.

The case also demonstrates how island isolation can decrease because of increasing accessibility (Jackson, 2008). Con Dao's isolation has been eroded, with more and more visitors arriving over the past five years. The archipelago's permeability is growing not on account of fixed links (Baldacchino, 2007; Larsen, 2014) but moveable links (ferries, airlines). Nevertheless, the dark and light imaginaries implicitly make visitors think about the island's isolation through historic events and stories in collective memories about Vietnam's heroes 
during colonial times. This partly denotes what Relph (1976) calls "a psycho-social need for assured roots" or "the emotional anchor [...] of coming from." For Con Dao, however, it is not the islanders' emotional anchor about where they "come from" but that of Vietnamese about where their national heroes belong as a result of their sacrifice. This unique emotional anchor makes Con Dao, in Harvey's (2000) terms, a "site of collective memory." It also indicates how associations of characteristic island isolation, sacredness, and nature are not necessarily destroyed by and can even be reinforced by increased connectivity (Zhang \& Grydehøj, 2020).

\section{Conclusion}

The case of dark tourism in Con Dao highlights the interconnection between tourism imaginaries and visitors' selective perceptions in transforming the meanings of dark places and thus shaping people' motivations to see these places. The presentation and consumption of tourism images nevertheless exposes a tension between tourism commodification and heritage conservation, resulting in an unexpected change in heritage narratives. The findings of this paper should inform policymakers in tourism development and heritage conservation to find a balanced solution for both activities. It might be possible to draw upon the spiritual dimension to develop more convincing narratives about the environment.

The effect of 'spiritual' tourism on visitors' perceptions toward both historical and natural heritage as well as issues of sustainability and over-tourism during peak periods requires further study. Because Con Dao provided an isolated case study, more research looking at other islands with similar dark histories during the first and second Indochina wars in Vietnam are also needed to confirm whether there is a similar pattern in terms of the impacts of tourism imaginaries and visitors' selective perceptions on motivations to visit dark places. Furthermore, since the research only focuses on Vietnamese visitors, a comparative study targeting foreign tourists is necessary to investigate the effect of culture and beliefs on visitors' selective perceptions.

\section{Acknowledgments}

The research was funded by the Newton Mobility Grant (British Academy), under Grant NMGR1180418: Between Dark Heritages and Ecotourism: Post-Colonial Ecologies in Vietnam (2018-2019).

\section{References}

Anh, V.T.T. (2015). The modernization of Đạo Mẫu: The impact of political ideology and commercialism on the worship of the Mother Goddess in Vietnam. Journal of Indigenous Social Development, 4(1), 1-17.

Ari, N. (1999). Vietnam's Doi Moi policy and forest protection. The possibility of people's participation. A step toward forest conservation strategy. IGES Forest Conservation Project Interim Report.

Ato Quayson, F.B.A. (2020, January 2). What is colonial literature? British Academy. https://www.thebritishacademy.ac.uk/blog/what-is-postcolonial-literature/ 
Baldacchino, G. (2007). Fixed links and the engagement of islandness: Reviewing the impact of the Confederation Bridge. The Canadian Geographer/Le Geographe Canadien, 51(3), 323-336. https://doi.org/10.1111/j.1541-0064.2007.00181.x

BBC Travel (2015). Vietnam-prison paradise. www.bbc.com/travel/story/20150914vietnams-prison-island-paradise

Beresford, M. (2008). Doi Moi in review: The challenges of building market socialism in Vietnam. Journal of Contemporary Asia, 38(2), 221-243. https://doi.org/10.1080/00472330701822314

Biran, A., Poria, Y., \& Oren, G. (2011). Sought experiences at (dark) heritage sites. Annals of Tourism Research, 38(3), 820-841. https://doi.org/10.1016/j.annals.2010.12.001

Bruner, E. (2005). Culture on tour: Ethnographies of travel. University of Chicago Press.

Burners, P.M. (2012). Controversies in tourism. CABI.

Chi, C.G.Q., \& Qu, H. (2008). Examining the structural relationships of destination image, tourist satisfaction and destination loyalty: An integrated approach. Tourism Management, 29(4), 624-636. https://doi.org/10.1016/j.tourman.2007.06.007

Chronis, A. (2012). Between place and story: Gettysburg as tourism imaginary. Annals of Tourism Research, 39(4), 797-1816. https://doi.org/10.1016/j.annals.2012.05.028

Con Dao National Park (2019). Vườn quốc gia Côn Đảo. Con Dao National Park. http:// www.condaopark.com.vn

Con Dao Tourism (2019). Du lịch Côn Đảo. Con Dao Tourism. http://www.condaotourism.com

Dark-tourism.com (2020). Ground zero. www.dark-tourism.com. https://www.darktourism.com/index.php/usa/15-countries/individual-chapters/720-ground-zero

Dann, G.M. (1998). The dark side of tourism. CIRET-International Center for Research and Studies in Tourism.

Duong, K.L., \& Bế, T.T. (2012). Côn Đảo qua môt số báo chí Saigon trước năm 1975. Hội thảo Côn Đảo-150 năm đấu tranh, xây dựng và phát triển (1862-2012), Du lịch.

Dujmovic, M. (2015, April). Postmodern society and tourism. In 3rd International Scientific Conference Tourism in Southern and Eastern Europe.

Fiditour (2019). Du lich Con Dao. Fiditour. www.fiditour.com.vn

Fakaye, P.C., \& Crompton, J.L. (1991). Image differences between prospective, first-time and repeat visitors to the lower Rio Grande Valley. Journal of Travel Research, 30(2), 10-16. https://doi.org/10.1177/004728759103000202

Foley, M., \& Lennon, J. J. (1996). JFK and dark tourism: A fascination with assassination. International Journal of Heritage Studies, 2(4), 198-211. https://doi.org/10.1080/13527259608722175

Government of Vietnam (2011). Quyết định Số: 2473/QĐ-TTg ngày 30 tháng 12 năm 2011 Thủ Tướng Chính Phủ về Chiến lược Phát triển Du lịch Việt Nam đến năm 2020, tầm nhìn đến 2030 (Decision No. 2473/QĐ-TTg, December 30, 2011 by the Prime Minister on Vietnam Tourism Development Strategy to 2020, with a vision to 2030). Hanoi.

Haarhoff, R. (2018). Tourist perceptions of factors influencing destination image: a case study of selected Kimberley resorts. African Journal of Hospitality, Tourism and Leisure, 7(4). 
Hall, C.M. (2012). Island, islandness, vulnerability and resilience. Tourism Recreation Research, 37(2), 177-181. https://doi.org/10.1080/02508281.2012.11081703

Harrison, R., \& Schofield, J. (2010). After modernity: Archaeological approaches to the contemporary past. Oxford University Press.

Harvey, D. (2000). Spaces of hope. University of California Press.

Hayward, P., \& Tran, G.T.H. (2014). At the edge: Heritage and tourism development in Vietnam's Con Dao archipelago. Journal of Marine and Island Cultures, 3(2), 113 124. https://doi.org/10.1016/j.imic.2014.10.002

Hooper, G., \& Lennon, J. (2016). Dark tourism. Taylor \& Francis.

Hudson, S. (2008). Tourism and hospitality marketing: A global perspective. Sage.

Huy Han (2019). Ngày hội ngộ (Reunion Day). Sụ Kiện và Nhân chưng. https://sknc.qdnd.vn/anh-mot-thoi/ngay-hoi-ngo-501342

Huong Giang, \& Minh Phuong (2013). Chuyện kể xúc động về một người tù Côn đảo. Nguời Đua Tin Nline. https://www.nguoiduatin.vn/chuyen-ke-xuc-dong-ve-mot-nguoi-tucon-dao-a66985.html

Isaac, R.K., \& Çakmak, E. (2014). Understanding visitor's motivation at sites of death and disaster: The case of former transit camp Westerbork, The Netherlands. Current Issues in Tourism, 17(2), 164-179. https://doi.org/10.1080/13683500.2013.776021

Jackson, R.E. (2008). Islands on the edge: Exploring islandness and development in four Australian case studies. Doctoral dissertation, University of Tasmania.

Johnson, E.L., \& Brezault, É. (Eds.) (2017). Memory as colonial capital: Cross-cultural encounters in French and English. Springer.

Korstanje, M.E., \& Ivanov, S.H. (2012). Tourism as a form of new psychological resilience: The inception of dark tourism. CULTUr-revista de Cultura e Turismo, 6(4), 56-71. https://doi.org/10.2139/ssrn.2168400

Larsen, J. (2014). The tourist gaze 1.0, 2.0, and 3.0. In A.A. Lew, C.M. Hall, \& A.M. Williams (Eds.). The Wiley Blackwell companion to tourism (pp. 304-313). Wiley. https://doi.org/10.1002/9781118474648.ch24

Lennon, J., \& Foley, M. (2000). Dark tourism: The attraction of death and disaster. Continuum.

Lennon, J., \& Mitchell, M. (2007). Dark tourism: The role of sites of death in tourism. In M. Mitchell (Ed.). Remember me: Constructing immortality. Beliefs on immortality, life and death. Routledge. https://doi.org/10.4324/9780203844540

Leite, N., Castañeda, Q.E., \& Adams, K.M. (2019). The ethnography of tourism: Edward Bruner and beyond. Lexington Books \& Rowman \& Littlefield

Lin, C.H., Morais, B., Kerstetter, D.L., \& Hou, J.S. (2007). Examining the role of cognitive and affective image in predicting choice across natural, developed, and theme-park destinations. Journal of Travel Research, 46(2), 183-194. https://doi.org/10.1177/0047287506304049

Litchee Travel (2020). Du lịch Côn Đảo. www.litcheetravel.com.

Lien Bang Travel (2020). Tour du lịch Côn Đảo. Lien Bang Travel. https://www.lienbangtravel.com/tour-du-lich-con-dao.html

Lonely Planet (2016). Con Dao Island. Lonely Planet. https://www.lonelyplanet.com/vietnam/around-ho-chi-minh-city/con-dao-islands 
Luce, D. (1970). The tiger cages of Vietnam. Historians against War. https://www.historiansagainstwar.org/resources/torture/luce.html

Luo, B., \& Grydehøj, A. (2017). Sacred islands and island symbolism in Ancient and Imperial China: an exercise in decolonial island studies. Island Studies Journal, 12(2), 25-44. https://doi.org/10.24043/isj.19

LĐO (2018). Việt Nam và Mỹ cần gác lại quá khứ và hướng đến tương lai. Lao Động Nline. https://laodong.vn/thoi-su/viet-nam-va-my-can-gac-lai-qua-khu-huong-toi-tuong-lai$\underline{588345.1 \mathrm{do}}$

Miles, W.F. (2002). Auschwitz: Museum interpretation and darker tourism. Annals of Tourism Research, 29(4), 1175-1178. https://doi.org/10.1016/s0160-7383(02)00054$\underline{3}$

Moutinho, L. (1987). Consumer behaviour in tourism. European Journal of Marketing, 21(10), 5-44.

Moutinho, L., \& Vargas-Sanchez, A. (Eds.). (2018). Strategic management in tourism. Cabi.

Mountz, A., \& Briskman, L. (2012). Introducing island detentions: The placement of asylum seekers and migrants on islands. Shima, 6(2), 21-26.

Nguyen, Thi Minh Nguyet (2016). Tổng quan nghiên cứu về du lịch sinh thái. Tạp chí Văn hóa Nghệ thuật số 382, 4, 2016.

Nguyen, Thi Anh Nguyet. (2012). Vài nét về công cuộc khẩn hoang, phát triển kinh tế ở Côn Đảo từ thế kỷ XVII đến đầu thế kỷ XIX. Kỷ yếu Hội thảo Côn Đảo-150 năm đấu tranh xây dựng và phát triển (1862-2012), Thành phố Vũng Tàu, 8/2012. Hanoi: NXB Chính trị Quốc gia.

Prayag, G. (2009). Tourists' evaluations of destination image, satisfaction, and future behavioral intentions: The case of Mauritius. Journal of Travel \& Tourism Marketing, 26(8), 836-853. https://doi.org/10.1080/10548400903358729

Phạm, Trung Lương (2017). Tiềm năng và triển vọng du lịch sinh thái tại Việt Nam. Tạp chí Môi truờng số 2/2017.

Pham, Van Thinh (2014). Tự học của những nhà yêu nước trong nhà tù Côn Đảo. Bà RịaVũng Tàu: Bảo tàng Bà Rịa- Vũng Tàu. https://www.baotangbrvt.org.vn/index.php?Module=Content\&Action=view\&id $=358$ \&Itemid=261

Phùng, Thi Huong (2019). Tù chính trị Côn Đảo đấu tranh bảo vệ lý tưởng cộng sản, một biểu tượng của chủ nghĩa anh hùng cách mạng Việt Nam. Bà Rịa-Vũng tàu: Bảo tàng Bà Rịa-Vũng Tàu.

Ragavan, N.A., Subramonian, H., \& Sharif, S.P. (2014). Tourists' perceptions of destination travel attributes: An application to International tourists to Kuala Lumpur. ProcediaSocial and Behavioral Sciences, 144, 403-411. https://doi.org/10.1016/j.sbspro.2014.07.309

Relph, E. (1976). Place and placelessness. Pion.

Reisinger, Y., \& Dimanche, F. (2010). International tourism. Abingdon: Routledge.

Ringer, G. (2012). Convicts and conservation: Con Dao National Park, Vietnam. In R. Harris, P. Williams, \& T. Griffin (Eds.). Sustainable tourism (pp. 239-255). Routledge. https://doi.org/10.1016/b978-0-7506-8946-5.50018-6 
Rittichainuwat, B.N. (2013). Tourists' and tourism suppliers' perceptions toward crisis management on tsunami. Tourism Management, 34, 112-121. https://doi.org/10.1016/j.tourman.2012.03.018

Salazar, N.B. (2012). Tourism imaginaries: A conceptual approach. Annals of Tourism Research, 39(2), 863-882. https://doi.org/10.1016/j.annals.2011.10.004

Schneider, K. (2015). It's was a true hell on earth. News.co.au. http://www.news.com.au/travel/world-travel/asia/it-was-a-true-hell-on-earth/newsstory/e3588d51d331a245b24cb91abd6c0913

Seaton, A.V., \& Bennett, M. M. (1996). The marketing of tourism products: Concepts, issues and cases. Cengage Learning EMEA.

Stone, P.R. (2012). Dark tourism and significant other death: Towards a model of mortality mediation. Annals of Tourism Research, 39(3), 1565-1587. https://doi.org/10.1016/j.annals.2012.04.007

Stone, P.R. (2006). A dark tourism spectrum: Towards a typology of death and macabre related tourist sites, attractions and exhibitions. Turizam: međunarodni znanstvenostručni časopis, 54(2), 145-160.

Stone, P.R. (2005). Consuming dark tourism: A call for research. eReview of Tourism Research 3(5), 109-117. https://doi.org/10.1016/j.annals.2008.02.003

Stone, P., \& Sharpley, R. (2008). Consuming dark tourism: A thanatological perspective. Annals of Tourism Research, 35(2), 574-595.

Sylvester, Y., \& Cherry, L. (2007). Perception and attitude of Hong Kong hotel guest-contact employees towards tourist from Mainland China. International Journal of Tourism Research, 9, 395-407. https://doi.org/10.1002/jtr.611

Thống, N.Đ. (2010). Lịch sủ nhà tù Côn Đảo (1862-1975). Thành phố Hồ Chí Minh: NXB Thành phố HCM.

TN (2005). Gặp lại người tử tù trong bức ảnh ngày hội ngộ. Lao Động Online. https://nld.com.vn/van-hoa-van-nghe/gap-lai-nguoi-tu-tu-trong-buc-anh-ngay-hoingo-115361.htm 2/6

TTXVN (2015). Việt-Mỹ hướng đến tương lai. Thanh nien Online. https://thanhnien.vn/thegioi/viet-my-huong-toi-tuong-lai-583015.html

Urry, J. (2001). Globalising the tourist gaze. In S.S. Babu, S. Mishra, \& B.B. Parida (Eds.). Tourism development revisited: Concepts, issues and paradigms (pp. 150-160). Response. https://doi.org/10.4135/9788132100058.n10

Viet Quang (2016). Khép lại quá khứ” nhưng không được bóp méo lịch sử. Nhân Dân Online. https://www.nhandan.com.vn/chinhtri/binh-luan-phe-

phan/item/29319402-\%E2\%80\%9Ckhep-lai-qua-khu\%E2\%80\%9D-nhung-khongduoc-bop-meo-lich-su.html

VietSenseTravel (2019). Du lịch Côn Đảo.VietSense Travel. https://todata.vn

Vietravel (2019). Du lịch Côn Đảo. Vietravel. http://Vietraveltravel.com.vn

Vntrip.vn (2020). Du lịch Côn Đảo. Vntrip.vn. www.vntrip.vn

Vu, T.A.T. (2006). Worshipping the Mother Goddess. The Dao Mao movement in Northern Vietnam. Explorations in Southeast Asian Studies, 6(1), 27-44.

Zoom Travel (2019). Côn Đảo. Zoom Travel. www.zoomtravel.com.vn 
Welch, M. (2015). Escape to prison: Penal tourism and the pull of punishment. University of California Press. https://doi.org/10.1525/9780520961500

Wilson, J.Z. (2004). Dark tourism and the celebrity prisoner: Front and back regions in representations of an Australian historical prison. Journal of Australian Studies, 82, 171-173. https://doi.org/10.1080/14443050409387951

Zhang, H., \& Grydehøj, A. (2020). Locating the interstitial island: Integration of Zhoushan Archipelago into the Yangtze River Delta urban agglomeration. Urban Studies. Epub ahead of print. https://doi.org/10.1177/0042098020937987 